\title{
CASP
}

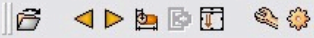

\section{- Comet (1/1): test01. tif}

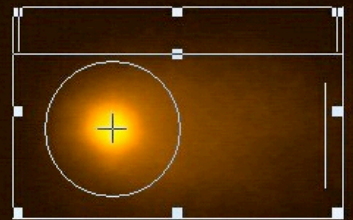

\section{- $\square X$ Os Profiles}

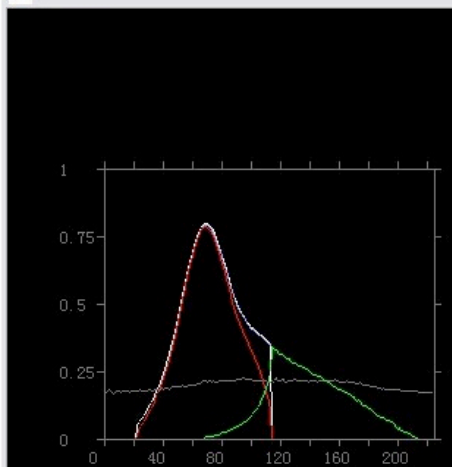

$-\square \times$ - $\begin{gathered}- \\ 1\end{gathered}$ 『 Cell

$\checkmark$ Comet

$\sqrt{\checkmark}$ Head

$\sqrt{\checkmark}$ Tail

ॠ $\mathrm{Bkg}$

Head

$\checkmark$ Head cont.

$\square$ Head

$\checkmark$ center

$\Gamma$ Tail

『 Tail

length

$\Gamma$ Hegat.

Г Mark

LHead $=93 \quad$ LTail $=99 \quad$ L omet $=192$

HeadDHA $=65.7255$ TailDHA $=34.2745$

$\mathrm{TM}=33.9318 \quad$ OTM $=23.4224$ 